\title{
The Spanish smoking law: a model to be followed?
}

\author{
María José López
}

Published online: 25 February 2010

(C) Swiss School of Public Health 2010

During the last few years, numerous countries have developed and implemented smoking control policies (IARC 2009). However, the overall approach to tobacco control has been considerably different among them. In Spain, a new Smoking Law came into force in January 2006 (Ministerio de Sanidad 2005), including regulations on the sale, supply, consumption, and publicity of tobacco products (Fernández 2006). Among its main goals, the law intended to protect non-smokers from secondhand smoke (SHS). For this reason, smoking was prohibited in all enclosed public and private workplaces with the exception of the hospitality sector, where partial restrictions were established depending on the size of the venue. Hospitality venues larger than $100 \mathrm{~m}^{2}$ could be completely smoke-free, or keep a smoking section (up to $30 \%$ of the total area) physically separated and independently ventilated. Owners of venues smaller than $100 \mathrm{~m}^{2}$, however, might decide to be smoke-free or to allow smoking without restrictions.

The Spanish smoking law is currently being promoted by the tobacco industry as a "model" to be followed by other countries (Muggli et al. 2009; Schneider and PötschkeLanger 2008). However, the scientific evidence, far from supporting the partial restrictions, has clearly shown that total bans are the only way of protecting hospitality workers (IARC 2009). In Spain, where it is estimated that only

M. J. López belongs to the Smoking Working Group of the Spanish Society of Epidemiology.

M. J. López $(\square)$

Public Health Agency of Barcelona, Barcelona, Spain

e-mail: mjlopez@aspb.es

M. J. López

CIBER Epidemiología y Salud Pública (CIBERESP),

Barcelona, Spain
10-20\% of hospitality venues banned smoking (MartínLuengo 2007)-probably as a consequence of unfounded fears of a potential negative impact on sales-the studies evaluating the impact on SHS levels have shown extremely high levels of SHS exposure in most hospitality workers.

A recent overall evaluation study (GTT-SEE 2009) collected the scientific evidence of the impact of the Spanish law on different issues such as public attitudes regarding the law, tobacco consumption, secondhand smoke exposure or health effects. Regarding public attitudes, data from a national survey (CIS 2005) showed that in November 2005 more than $77 \%$ of the general population agreed with the smoking law that was going to be enacted. These data seem to be consistent with those shown in the paper of Halpern and Taylor (2009), where a strong support was found for smoking bans in workplaces in Spain (66\% employees and 97\% employers). The paper of Lazuras et al. (2009) shows that smokers are less supportive of smoke-free public places than nonsmokers, but both groups-smokers and non-smokers-are predominantly supportive of these measures, even in countries with pro-smoking social norms and high smoking rates. In Spain, where the support was also lower among smokers, regional surveys (Departament de Salut 2009) carried out before and after the implementation of the law, showed that this support increased after the law in both smokers and nonsmokers.

The impact of the law on tobacco consumption has also been analyzed. So far, the available information (GTT-SEE 2009) does not suggest any impact of the Spanish smoking law on the tobacco consumption indicators. The decrease in the prevalence of smokers and the number of cigarettes smoked, as well as the increase in quitting, continues the time trend observed before the implementation of the law, according to the expected smoking epidemic model evolution (Lopez et al. 1994). 
Concerning SHS exposure, studies with different approaches have measured the changes in SHS levels after the Spanish law by means of environmental and biological markers, such as vapor-phase nicotine or saliva cotinine (Fernández et al. 2009; Nebot et al. 2009). These studies have shown significant reductions on SHS levels in offices from the public and private sector (nicotine reductions of 60 and $97 \%$, respectively). In hospitality venues, however, significant reductions of SHS levels were found only in those hospitality venues where smoking was totally banned $(97 \%$ reduction), while in those where smoking has not been banned the levels of nicotine are associated with very high risks of lung cancer and other diseases. At the population level, the prevalence of SHS has significantly decreased in workplaces (more than $50 \%$ reduction), as shown by national and regional surveys conducted before and after the law (Galán et al. 2007; Jiménez-Ruiz et al. 2008).

Finally, with regard to health effects, reported respiratory symptoms were measured in Spanish hospitality workers before and after the law. The results have shown that workers from hospitality venues where smoking was totally banned reduced significantly the frequency of respiratory symptoms, while no differences were found in the other workers (Fernández et al. 2009). Furthermore, among the general population, the data available so far seem to show a significant reduction of hospital admissions for acute coronary syndrome after the implementation of the law (Villalbí et al. 2009). These findings, probably due to the smoking reduction in workplaces, would be consistent with those described by Goodman et al. (2009) after reviewing numerous evaluation studies of the health impact of smoking control laws.

In summary, the Spanish Smoking law seems to have had a very positive impact on different issues such as the reduction of SHS exposure in workplaces, but this is far from being a model to be followed. The protection of hospitality workers from secondhand smoke is probably the main issue to be faced, extending the smoking ban to all hospitality venues. Total bans would not only improve the health of these workers but would also avoid the current inequalities in working conditions. As stated in Goodman's review (Goodman et al. 2009), "There is no longer any reason why non-smokers should be exposed to SHS in any workplace".

\section{References}

Centro de Investigaciones Sociológicas (2005) Tabaquismo y nueva normativa anti-tabaco. Estudios 2627, 2665 y 2751. CIS, Madrid. Available at: http://www.cis.es/cis/opencm/ES/1_encuestas/
estudios/listaTematico.jsp?tema $=107 \&$ todos $=$ si. Accessed November 2009

Departament de Salut (2009) Estudis d'opinió davant la 1lei 28/2005. Generalitat de Catalunya, Barcelona. Available at: http://www. gencat.cat/salut/depsalut/html/ca/dir2074/doc12551.html. Accessed November 2009

Fernández E (2006) Spain going smoke-free. Tob Control 15:79-80

Fernández E, Fu M, Pascual JA, López MJ, Pérez-Ríos M, Schiaffino A et al (2009) Impact of the Spanish smoking control law on exposure to second-hand smoke and respiratory health in hospitality workers: a cohort study. PLoS ONE 4:e42-e44

Galán I, Mata N, Estrada C, Díez-Gañán L, Velázquez L, Zorrilla B, Gandarillas A, Ortiz H (2007) Impact of the "Tobacco control law" on exposure to environmental tobacco smoke in Spain. BMC Public Health 7:224-229

Goodman P, Haw S, Kabir Z, Clancy L (2009) Are there health benefits associated with comprehensive smoke-free laws. Int $\mathrm{J}$ Public Health 54:367-378

Grupo de Trabajo sobre Tabaquismo de la Sociedad Española de Epidemiología (2009) Evaluación del impacto de la Ley de medidas sanitarias frente al tabaquismo. Prodisa, Barcelona

Halpern M, Taylor H (2009) Beliefs regarding smoking in the workplace: results from the Global Workplace Smoking Survey. Int J Public Health 54:391-401

IARC (2003) Handbooks of cancer prevention, tobacco control, vol. 13. Evaluating the effectiveness of smoke-free policies. Lyon, France

Jiménez-Ruiz CA, Miranda JA, Hurt RD, Pinedo AR, Reina SS, Valero FC (2008) Study of the impact of laws regulating tobacco consumption on the prevalence of passive smoking in Spain. Eur J Public Health 18:622-625

Lazuras L, Rodafinos A, Panagiotakos DB, Thyrian JR, John U, Polychronopoulos E (2009) Support for smoke-free policies in a pro-smoking culture: findings from the European Survey on tobacco control attitudes and knowledge. Int J Public Health 54:403-408

Lopez AD, Collishaw NE, Piha T (1994) A descriptive model of the cigarette epidemic in developed countries. Tob Control 3:242247

Ministerio de Sanidad y Consumo. Ley 28/2005, de 26 de diciembre, de medidas sanitarias frente al tabaquismo y reguladora de la venta, el suministro, el consumo y la publicidad de los productos del tabaco. Available at http://www.msc.es/novedades/docs/ disposicionesGenerales.pdf. Accessed January 2010

Martín-Luengo IA (2007) 500 días de la ley contra el tabaquismo. OCU-Salud 72:13-17

Muggli ME, Lockhart NJ, Ebbert JO, Jiménez-Ruiz CA, Miranda JA, Hurt RD (2009) Legislating tolerance: Spain's national public smoking law. Tob Control. doi:10.1136/tc.2009.031831

Nebot M, Lopez MJ, Ariza C, Pérez-Ríos M, Fu M, Schiaffino A et al (2009) Impact of the Spanish Smoking Law on exposure to secondhand smoke in offices and hospitality venues: before and after study. Environ Health Perspect 117:344-347

Schneider NK, Pötschke-Langer M (2008) The "Spanish Model" of non-smoker protection in hospitality venues: a failed approach. German Cancer Research Center, Heidelberg. Available at http://www.tabakkontrolle.de/pdf/AdWfP_The_spanish_Model_ engl.pdf. Accessed November 2009

Villalbí JR, Castillo A, Cleries M, Saltó E, Sánchez E, Martínez R, Tresserras R, Vela E; Barcelona Group (2009) Acute myocardial infarction hospitalization statistics: apparent decline accompanying an increase in smoke-free areas. Rev Esp Cardiol 62:812815 